Bolleli, T.M., Lense, G.H.E, Santana, D.B., Moreira, R.S., Sestras, P., Spalevic, V., Mincato, R.L. (2020): Estimates of soil losses in watershed under tropical of altitude climate in Brazil. Agriculture and Forestry, 66 (4): $73-88$.

DOI: 10.17707/AgricultForest.66.4.06

Talyson de Melo BOLLELI ${ }^{1}$, Guilherme Henrique Expedito LENSE ${ }^{1}$, Derielsen Brandão SANTANA ${ }^{2}$, Rodrigo Santos MOREIRA ${ }^{1}$, Paul SESTRAS ${ }^{2}$, Velibor SPALEVIC ${ }^{3}$, Ronaldo Luiz MINCATO ${ }^{1}$

\title{
ESTIMATES OF SOIL LOSSES IN WATERSHED UNDER TROPICAL OF ALTITUDE CLIMATE IN BRAZIL
}

\section{SUMMARY}

Water erosion is one of the main degradation processes of tropical soils. In steepest areas with coffee cultivation, the erosion rates are intensified and could reach levels above the Soil Loss Tolerance Limits (T). Thus, the objective of this work was to evaluate the susceptibility to water erosion in steepest areas under predominant coffee cultivation using the Revised Universal Soil Loss Equation (RUSLE) and compare the results to $\mathrm{T}$ limit. The research was carried out at the Ribeirão José Lúcio subbasin located in Conceição do Rio Verde Municipality and the Ribeirão São Bento subbasin located in Cambuquira Municipality, both in South of Minas Gerais State, Brazil. The parameters involved in the RUSLE and $\mathrm{T}$ calculations were determined from the physical and edaphoclimatic characteristics of the subbasins. The total soil loss of the Ribeirão São Bento subbasin was 1,032 $\mathrm{Mg}_{\text {year }}{ }^{-1}$, while the Ribeirão José Lúcio subbasin present an erosion rate of $5,014 \mathrm{Mg}$ year $^{-1}$ with $13.16 \%$ and $7.90 \%$ of the areas above the $\mathrm{T}$ limits, respectively.

We found the highest losses in steepest and exposed soil areas, which should be prioritized in the adoption of conservation management practices, seeking to minimize water erosion, and ensuring the long-term sustainability of agricultural production. The RUSLE model is a fast, simple, and inexpensive tool that contributes to the assessment of soil conservation in hydrographic subbasins.

Keywords: Erosion Modeling, Soil Conservation, Water Erosion, Revised Universal Soil Loss Equation, RUSLE.

\footnotetext{
${ }^{1}$ Ronaldo Luiz Mincato (corresponding author: ronaldo.mincato@unifal-mg.edu.br), Talyson de Melo Bolleli, Guilherme Henrique Expedito Lense, Derielsen Brandão Santana, Rodrigo Santos Moreira, Universidade Federal de Alfenas - UNIFAL-MG, Alfenas, Minas Gerais, BRAZIL.

${ }^{2}$ Department of Terrestrial Measurement and Cadastre, Faculty of Civil Engineering, Technical University of Cluj-Napoca, Cluj-Napoca, ROMANIA.

3 Velibor Spalevic, University of Montenegro, Faculty of Philosophy, Geography, Niksic, MONTENEGRO.

Paper presented at the GEA (Geo Eco-Eco Agro) International Conference 2020, Podgorica.

Notes: The authors declare that they have no conflicts of interest. Authorship Form signed online.

Received:01/11/2020

Accepted:28/1 1/2020
} 


\section{INTRODUCTION}

Soil is one of the most important and most complex natural resources, but current developments (climate change, soil erosion, and urbanization) increasingly threaten this valuable resource (Ayer et al., 2020; Spalevic et al., 2020; Chalise et al., 2019; Parsipour et al., 2019; Curovic et al., 2019.). Soils are essential for food production and various other ecosystem goods and services, including climate regulation and nutrient cycling (Greiner et al., 2017).

Soil degradation caused by erosion and rapid population increase is ranked among the most important environmental problems in the world (Khaledi Darvishan et al., 2019; Dimotta et al., 2017; Spalevic et al., 2016; Dimotta et al., 2016). Erosion is a key driver of land degradation, heavily affecting sustainable land management in various environments worldwide (Ouallali et al., 2019; Tavares et al., 2019; El Mouatassime et al., 2019; Nikolic et al., 2018; Spalevic, 2011). Water erosion is one of the main processes of tropical soil degradation and causes organic matter and nutrients losses, compromising the provision of soil ecosystem services (Olivetti et al., 2015; Bertol et al., 2007). According to Lal (2014), 1 billion hectares worldwide have already been affected by the erosion process, of which $70 \%$ are seriously committed to agricultural production. The worldwide annual rate of soil erosion from agricultural land ranges from 22 to $100 \mathrm{t} \mathrm{ha}^{-1}$; declines in productivity as much as $15-30 \%$ annually (Morgan, 2005).

Estimating soil loss and identifying hotspot areas support combating soil degradation (Girmay et al., 2020). Direct field measurements of soil erosion at permanent research or experimental stations using runoff plots with the known area, slope gradient slope length, and soil type could give reliable runoff and soil loss (Hurni et al., 2010) for experimental purposes, however, it is costly, laborintensive, and time-consuming (Alemayehu \& Alamirew, 2012). Empiricalstatistical models were developed and improved to evaluate and quantify water erosion (Hazbavi et al., 2020; Amorim et al., 2010; Spalevic, 1999). These models include the Universal Soil Loss Equation - USLE (Wischmeier and Smith, 1978) and the Revised Universal Soil Loss Equation - RUSLE (Renard et al., 1997). RUSLE has a simple application and can be adapted to new geographical and edafoclimatic conditions. Moreover, combined this model with geographic information systems (GIS), it is possible to assess the spatial distribution of soil losses and identify areas most susceptible to erosion (Avanzi et al., 2013). Furthermore, soil losses can be compared with the soil loss tolerance (T) limits, which represent the maximum erosion rate that allows sustainable agricultural production (Wischmeier and Smith, 1978).

Coffee is the main agricultural crop in southern Minas Gerais, with economic and social prominence. Coffee plantations are concentrated in steepest areas, which are more vulnerable to water erosion. However, few studies evaluate the dynamics of the erosive process in these areas. Thus, the objective of this work was to evaluate the susceptibility to water erosion in steepest areas under predominant coffee cultivation using the RUSLE and compare the results to the T limit. 


\section{Study area}

\section{MATERIAL AND METHODS}

The research was carried out at the Ribeirão José Lúcio subbasin located in Conceição do Rio Verde Municipality, coordinated 473000 at $477000 \mathrm{~m} \mathrm{~W}$ and 7581000 at $7584000 \mathrm{~m} \mathrm{~S}$, and the Ribeirão São Bento subbasin located in Cambuquira Municipality, coordinates 479000 to $484000 \mathrm{~m} \mathrm{~W}$ and 7570000 to $7575000 \mathrm{~m} \mathrm{~S}$, Datum SIRGAS 2000, zone 23K UTM, both in southern Minas Gerais, at high altitudes (>1000 m) in Serra da Mantiqueira, Brazil (Figure 1).

According to the Köppen system, the climate is classified as humid mesothermal, tropical of altitude subtype $(\mathrm{Cwb})$, with an average temperature of $20^{\circ} \mathrm{C}$ and precipitation between 1,480 to $1,700 \mathrm{~mm}$ (Sparovek et al., 2007). In both municipalities, coffee production is the main economic activity (Figure 1).

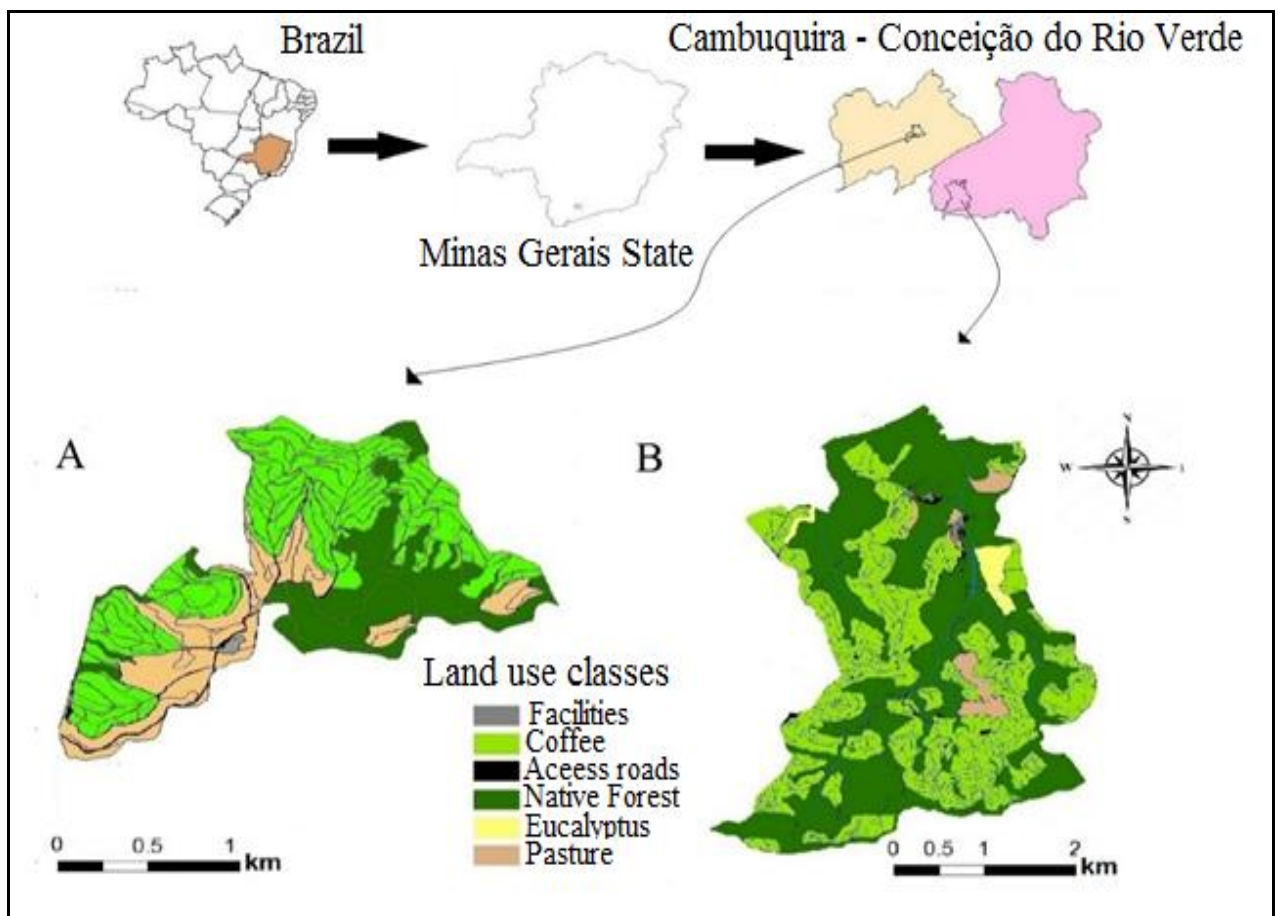

Figure 1: Location and land use and occupation maps in the Ribeirão São Bento (A) and Ribeirão José Lucio (B) sub-basins respectively in the municipalities of Cambuquira and Conceição do Rio Verde, southern of Minas Gerais, Brazil.

The elaboration of the land use map was made from the cartographic base and the crops mapped by Ipanema Agricola SA (Ipanema Coffees), and Landsat8 Operational Land Imager (OLI) satellite images, bands 2, 3 and 4, corresponding to Orbit / Point 219/75 from Imaging Division (DIDGI) (INPE, 2019). The images were composting in ArcGIS 10.2 (ESRI, 2014), and the accuracy was verified in field surveys, with a 95\% accuracy rate. Occupancy rates for land use classes are shown in Table 1. 
Table 1: Land use and occupation classes in the Ribeirão São Bento and Ribeirão José Lúcio subbasins.

\begin{tabular}{llllll}
\hline \multicolumn{2}{l}{ Ribeirão São Bento } & \multicolumn{4}{l}{ Ribeirão José Lúcio } \\
\hline Land use & Area (ha) & $\begin{array}{l}\text { Area } \\
(\%)\end{array}$ & Land use & Area (ha) & $\begin{array}{l}\text { Area } \\
(\%)\end{array}$ \\
\hline Access roads & 19.88 & 5.97 & Access roads & 80.20 & 5.91 \\
Facilities & 1.17 & 0.35 & Facilities & 18.18 & 1.22 \\
Coffee & 147.74 & 43.55 & Coffee & 543.94 & 40.26 \\
Native forest & 94.46 & 27.82 & Native forest & 669.01 & 49.35 \\
Pasture & 75.95 & 22.31 & Pasture & 34.05 & 2.52 \\
& ---- & --- & Eucalyptus & 23.18 & 1.72 \\
\hline TOTAL & 332.92 & 100 & TOTAL & 1355.39 & 100 \\
\hline
\end{tabular}

The altitudes range from 893 to $1,339 \mathrm{~m}$ and 849 to $1,096 \mathrm{~m}$ for the Ribeirão José Lúcio and Ribeirão São Bento sub-basins, respectively (Fig. 2). The digital elevation model (DEM), with spatial resolution of $12.5 \mathrm{~m}$, was made from the contours extracted from the topographic map of Varginha (IBGE, 1979) and São Lourenço (IBGE, 1971), with the ArcGis 10.2 tool to Raster (ESRI, 2014).

The slope map was generated (Figure 2) using the DEM by the ArcGis 10.2 Slope tool (ESRI, 2014). The relief units were classified according to EMBRAPA (2011), in flat (0-3\%), slightly rolling (3-8\%), rolling (8-20\%), strongly rolling $(20-45 \%)$ and mountainous $(45-75 \%)$ relief. In both subbasins, there was a predominance of rolling and strongly rolling relief (Figure 2 ).

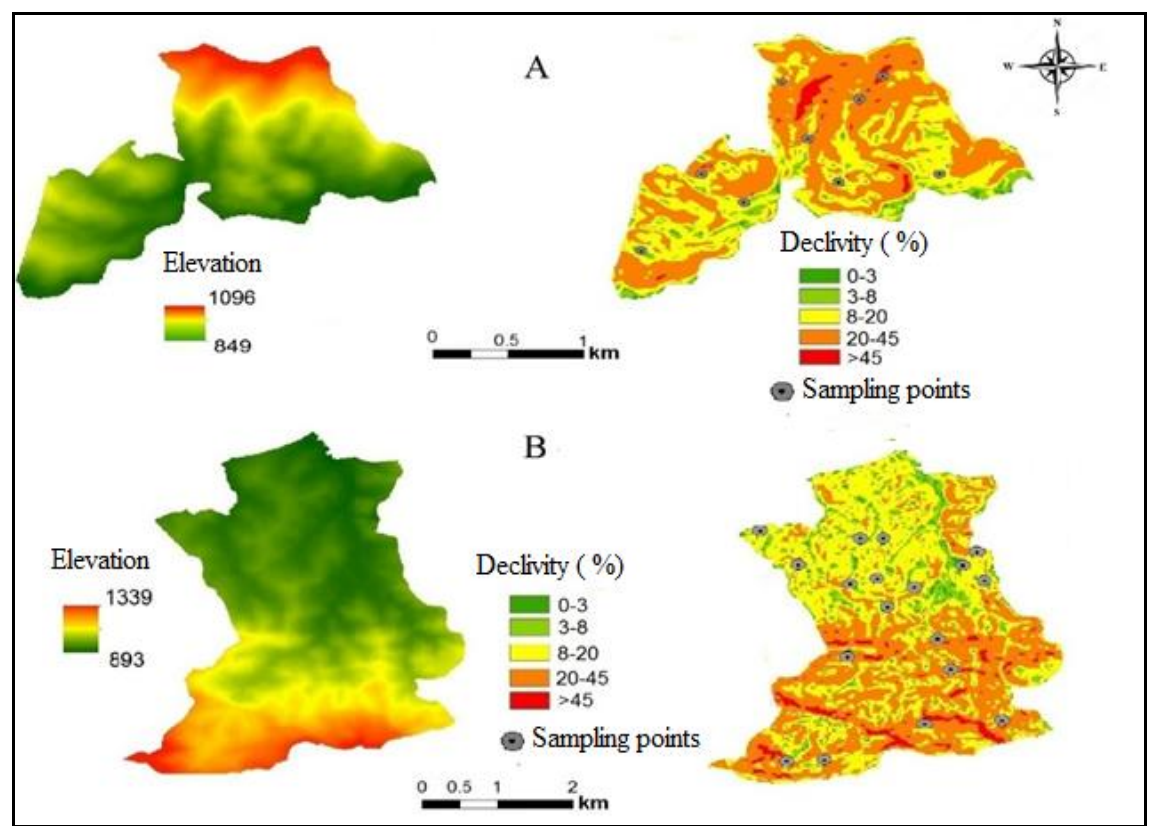

Figure 2: Digital Elevation Model (DEM) and Declivity maps in the Ribeirão São Bento (A) and Ribeirão José Lucio (B) subbasins in the respective Cambuquira and Conceição do Rio Verde Municipalities, Minas Gerais state, Brazil. 
The digital soil map (Figure 3) was elaborated from the Minas Gerais State Soil Map in the ArcGis 10.2 (ESRI, 2014), on a scale of 1: 650.000 (UFV et al., 2010) mutually with field surveys. We considered the relief as a base attribute of soil differentiation (McBratney et al., 2003).

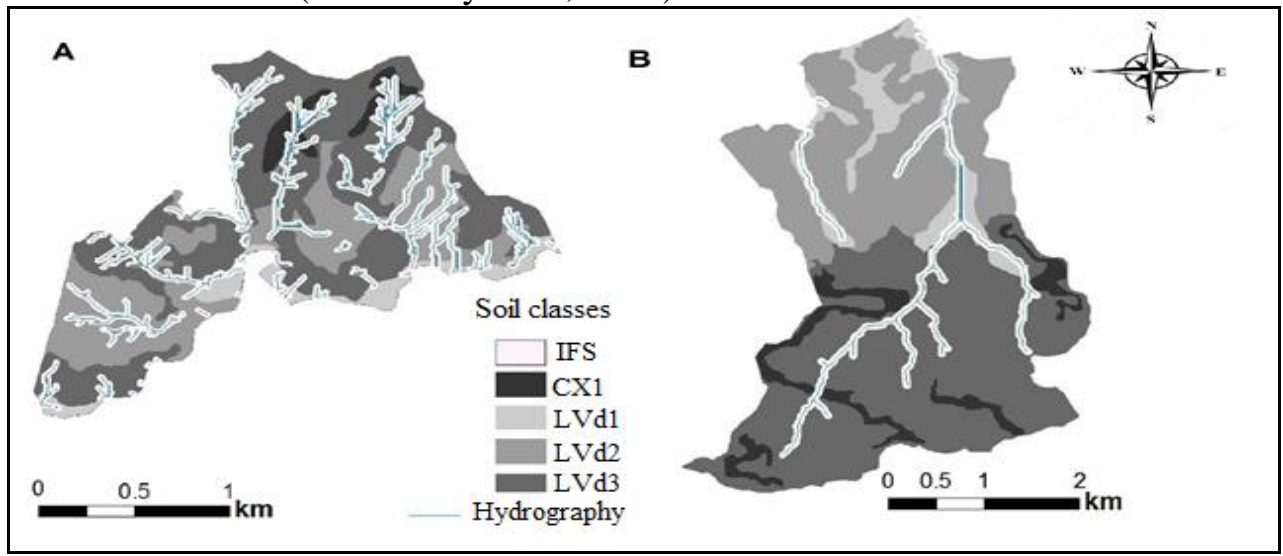

Figure 3: Digital soil maps: dystrophic red Latosol in a flat to slightly rolling relief (LVd1), dystrophic red Latosol in a rolling relief ( $\mathrm{LVd} 2)$, dystrophic red Latosol in a strongly rolling relief (LVd3), indiscriminate floodplain soils (IFS) and Haplic Cambisol

(CX1) in the Ribeirão São Bento (A) and Ribeirão José Lucio (B) subbasins in the respective Cambuquira and Conceição do Rio Verde Municipalities, Minas Gerais State, Brazil.

The soils of the Ribeirão São Bento and Ribeirão José Lúcio sub-basins were classified as Latossolo Vermelho Distrófico in flat to slightly rolling reliefs (LVd1), rolling ( $\mathrm{LVd} 2)$, strongly rolling (LVd3); Cambissolo (CX1) in mountainous relief and indiscriminate lowland soils (IFS), according to the Brazilian Soil Classification System (Santos et al., 2013) (Table 2).

Table 2: Soil classes, Ribeirão São Bento and Ribeirão José Lúcio subbasins.

\begin{tabular}{llllll}
\hline Ribeirão São Bento & \multicolumn{5}{l}{ Ribeirão José Lúcio } \\
\hline Soil classes & Area (ha) & Area $(\%)$ & Soil & Area (ha) & Area $(\%)$ \\
\hline CX1 & 7.59 & 2.27 & CX1 & 94.10 & 6.94 \\
LVd1 & 20.86 & 6.26 & LVd1 & 121.16 & 8.88 \\
LVd2 & 108.11 & 32.47 & LVd2 & 411.90 & 30.43 \\
LVd3 & 151.56 & 45.55 & LVd3 & 676.03 & 49.87 \\
IFS & 44.80 & 13.45 & SIV & 52.20 & 3.90 \\
\hline TOTAL & 332.92 & 100 & TOTAL & 1355.39 & 100 \\
\hline
\end{tabular}

CX1 = Haplic Cambisol; LVd1 = dystrophic red Latosol in a flat to slightly rolling relief; $\mathrm{LVd} 2=$ dystrophic red Latosol in a rolling relief; $\mathrm{LVd} 3=$ dystrophic red Latosol in a strongly rolling relief; IFS = indiscriminate floodplain soils. 


\section{Field sampling}

Soil samples were collected based on land use and relief classes in 9 points at the Ribeirão José Lúcio subbasin and 18 points at the Ribeirão São Bento subbasin (Figure 2). We collect three types of samples on the surface $(0$ to $20 \mathrm{~cm})$ and subsurface $(20$ to $40 \mathrm{~cm}$ ) soil layers: disturb, undisturbed by the clod method, and undisturbed with a cylindrical sampler (volume $92.53 \mathrm{~cm}^{3}$ and depth $5 \mathrm{~cm}$ ).

The following analyses were performed: particle size distribution with and without $\mathrm{NaOH}$ (Bouyoucos et al., 1962 ; Blake et al., 1986); organic matter (MO) by oxidation with $\mathrm{Na}_{2} \mathrm{Cr}_{2} \mathrm{O}_{7} 2$ mol L${ }^{-1}+\mathrm{H}_{2} \mathrm{SO}_{4} 5$ mol L${ }^{-1}$; $\mathrm{pH}$ with $\mathrm{KCl}$ and $\mathrm{CaCl}_{2}$ - 1: 2.5 ratio; sum of exchangeable bases $(\mathrm{SB})$; soil density by the volumetric ring method; cationic exchange capacity at $\mathrm{pH} 7.0$ (CEC-T) and effective cationic exchange capacity (CEC-t); aluminum saturation index (m), remaining phosphorus (P-rem), exchangeable $\mathrm{Ca}-\mathrm{Mg}$-Al with $1 \mathrm{~mol} \mathrm{~L}^{-1} \mathrm{KCl}$ extractor, $\mathrm{H}+$ Al with SMP extractor; available phosphorus (P) by the colorimetric method using ascorbic acid; base saturation index (V\%); flocculation index and water dispersed clay by the pipette method (Zhang, 1997); aggregate stability with weighted average diameter (MPD) and geometric mean diameter (DMG) calculation by wet sieving method and soil porosity with total pore volume calculation EMBRAPA (2011). The soil permeability variable was obtained in the field, from three replicates for each soil class with a Mini Disk Decagon Devices infiltrometer adjusted for the suction rate of $2 \mathrm{~cm}$ Zhang (1997). The moist color was visually classified according to the Munsell (2012) classification.

\section{Revised Universal Soil Loss Equation}

Soil loss rates at the study areas were calculated by the RUSLE (Equation 1) (Renard et al., 1997).

$$
A=R \cdot K \cdot L S \cdot C \cdot P
$$

(Equation 1)

Where: $\mathrm{A}$ is a mean annual soil loss, $\mathrm{Mg} \mathrm{ha}^{-1}$ year $^{-1} ; \mathrm{R}$ is the rainfall erosivity factor, $\mathrm{MJ} \mathrm{mm} \mathrm{ha}{ }^{-1} \mathrm{~h}^{-1}$ year ${ }^{-1}$; $\mathrm{K}$ is the soil erodibility factor, $\mathrm{Mg} \mathrm{h} \mathrm{MJ}^{-1} \mathrm{~mm}^{-1}$; LS is the topographic factor expressing slope and ramp length (dimensionless); $\mathrm{C}$ is the factor for land use and management (dimensionless), and $\mathrm{P}$ is the factor for conservation practices (dimensionless) (Wischmeier and Smith, 1978).

The $\mathrm{R}$ factor was obtained from the rainfall erosivity map for the southern Minas Gerais state, with values ranging in the two areas from 5,145 to 7,776 MJ $\mathrm{mm} \mathrm{ha}^{-1} \mathrm{~h}^{-1}$ year ${ }^{-1}$ with an average of 6,500 $\mathrm{MJ} \mathrm{mm} \mathrm{ha}{ }^{-1} \mathrm{~h}^{-1}$ year ${ }^{-1}$ (Aquino et al., 2012). The $\mathrm{K}$ factor represents soil resistance to erosion. To Cambisol this parameter was calculated by the indirect method of Bouyoucos (1962) (Equation 2) and to the Latosols by the indirect method of Silva et al. (1999) (Equation 3).

$\mathrm{K}=[(\%$ sand $+\%$ silt $) /(\%$ clay $)] / 100$

(Equation 2)

Where: K: average soil erodibility (Mg ha-1 MJ-1 mm-1); \% sand, \% silt, and \% clay $=$ percentages of the respective fractions of horizon A. The description and parameter values of Equation 2 are described in Table 3. 
Table 3. Soil resistance to erosion (K) to Cambisol, according to Equation 2.

\begin{tabular}{|c|c|c|c|c|c|c|}
\hline \multirow[b]{2}{*}{ Factor } & & \multicolumn{5}{|c|}{ Ribeirão São Bento } \\
\hline & & & $\%$ sand & $\%$ silt & $\%$ clay & K \\
\hline \multirow{3}{*}{$\mathrm{K}$} & \multirow{3}{*}{ Erodibility } & CX1 Horizon A & 70 & 11 & 19 & 0.043 \\
\hline & & \multicolumn{5}{|c|}{ Ribeirão José Lúcio } \\
\hline & & CX1 Horizon A & 67 & 16 & 17 & 0.048 \\
\hline
\end{tabular}

Cambisol (CX1).

$\mathrm{Y}=-3,89 \times 10^{-2}+5,11 \times 10^{-3} \mathrm{X}_{14}-1,25 \times 10^{-2} \mathrm{X}_{15}+5,41 \times 10^{-3} \mathrm{X}_{16}-7,27 \times 10^{-3}$ $\mathrm{X}_{18}+5,33 \times 10^{-2} \mathrm{X}_{33}+3,21 \times 10^{-5} \mathrm{X}_{34}-5,66 \times 10^{-5} \mathrm{X}_{36}+8,33 \times 10^{-4} \mathrm{X}_{2}-1,17 \mathrm{x}$ $10^{-2} \mathrm{X}_{4}+1,53 \times 10^{-2} \mathrm{X}_{13}$

(Equation 3)

Note: The description and parameter values of Equation 3 are described in Table 4. The values of the variables were obtained based on soil samples collected from the native forest.

Table 4. Soil resistance to erosion (K) to Latosols.

\begin{tabular}{|c|c|c|c|c|c|c|c|}
\hline \multirow[t]{3}{*}{ Param. } & \multirow[t]{3}{*}{ Description } & \multicolumn{3}{|c|}{ Ribeirão José Lúcio } & \multicolumn{3}{|c|}{ Ribeirão São Bento } \\
\hline & & \multicolumn{3}{|c|}{ Soil Classes } & \multicolumn{3}{|c|}{ Soil Classes } \\
\hline & & LV1 & LVD2 & LVD3 & LVD1 & LVD2 & LVD3 \\
\hline Y & K & 0.015 & 0.023 & 0.022 & 0.029 & 0.025 & 0.019 \\
\hline $\mathbf{X}_{2}$ & $\begin{array}{l}\text { CEC-T pH 7.0 } \\
\left(\mathrm{cmol}_{\mathrm{c}} \mathrm{kg}^{-1)}\right.\end{array}$ & 6.490 & 9.170 & 8.238 & 13.315 & 11.086 & 5.120 \\
\hline $\mathbf{X}_{4}$ & $\mathrm{pH}=\underset{(\operatorname{dim})}{\mathrm{pH}} \mathrm{KCL}^{\mathrm{pH} \mathrm{H}_{2} \mathrm{O}}$ & -1.430 & -0.710 & -0.908 & -0.820 & -0.749 & -0.753 \\
\hline $\mathbf{X}_{13}$ & KI relation(dim) & 1.330 & 1.330 & 1.330 & 1.330 & 1.330 & 1.330 \\
\hline $\mathbf{X}_{14}$ & MSM Munsell (dim) & 2.000 & 3.000 & 3.000 & 3.000 & 3.000 & 3.000 \\
\hline $\mathbf{X}_{15}$ & drainage (dim) & 4.000 & 4.000 & 4.000 & 4.000 & $4.00 \mathrm{~V} 0$ & 4.000 \\
\hline$X_{16}$ & Structure degree (dim) & 2.000 & 3.000 & 2.000 & 2.000 & 2.000 & 2.000 \\
\hline $\mathbf{X}_{18}$ & Structure shape (dim) & 3.000 & 3.000 & 3.000 & 3.000 & 3.000 & 3.000 \\
\hline $\mathbf{X}_{33}$ & (TPV) $\left(\mathrm{dm}^{3} \mathrm{dm}^{-3}\right)$ & 0.628 & 0.608 & 0.607 & 0.600 & 0.619 & 0.645 \\
\hline $\mathbf{X}_{34}$ & Flocculation index (dim) & 0.545 & 0.614 & 0.508 & 0.400 & 0.353 & 0.273 \\
\hline $\mathbf{X}_{36}$ & AS index $\left(\mathrm{G} \mathrm{KG}^{-1}\right)$ & 97.673 & 93.600 & 93.600 & 110.300 & 108.579 & 108.358 \\
\hline
\end{tabular}

Dystrophic red Latosol in a flat to slightly rolling relief (LVd1), dystrophic red Latosol in a rolling relief ( $\mathrm{LVd} 2)$, dystrophic red Latosol in a strongly rolling relief (LVd3), cation exchange capacity (CEC), Dimensionless (dim), Moist Soil Matrix (MSM), total pore volume (TPV); Aggregate stability (AS).

The LS topographic factor was estimated according to Moore and Burch (1986) in the ArcGIS 10.2 (ESRI, 2014) (Equation 4) from the DEM using the 
Raster Calculator tool. The model was efficient in determining LS, with higher factor values associated with steep slopes and more intense flows. The LS factor range from 0 to 238, with an average of 16.44 and 0 to 617, with an average of 7.28, for the Ribeirão São Bento and Ribeirão José Lúcio subbasins, respectively.

LS $=\left(\text { Slope Length } \times \frac{12.5}{22.13}\right)^{0.4} \cdot\left(0.01745 \times \frac{\text { Slope in Degree }}{0.0896}\right)^{1.4} \cdot 1.4 \quad$ (Equation 4)

Where: $\mathrm{LS}=$ topographic factor (dimensionless); 12.5 = DEM cell size.

To determine the $\mathrm{C}$ and $\mathrm{P}$ factors, we consult the specialized literature. Areas with exposed soil present the highest $\mathrm{C}$ values, followed by eucalyptus cultivated down the hill, coffee, degraded pasture, facilities, indiscriminate floodplain soils, and native forest (Table 5). The higher P factor was found in degraded pasture and exposed soils, while the lowest value found in the native forest was due to the dense vegetation cover $(0.01)$. Coffee presents a $\mathrm{P}$ factor of 0.50 due to conservationist practices.

Table 5. Land use and management $(\mathrm{C})$ and conservation practice $(\mathrm{P})$ factors for the Ribeirão São Bento and the Ribeirão José Lúcio subbasins.

\begin{tabular}{lccc}
\hline \multicolumn{1}{c}{$\begin{array}{c}\text { Land use and } \\
\text { occupation }\end{array}$} & Factor C & Source factor C & Factor P* \\
\hline Coffee (3.95 x 0.55 m) & 0.135 & Prochnow 2005 & 0.50 \\
Degraded pasture & 0.100 & Roose 1977 & 1.00 \\
Native forest & 0.001 & Silva 2016 & 0.01 \\
Floodplains soils & 0.004 & Oliveira 2007 & 0.00 \\
Facilities & 0.010 & Lin 2011 & 0.00 \\
Eucalyptus down the & 0.300 & Martins 2010 & 1.00 \\
hill & & & \\
Exposed soil & 1.000 & ---- & 1.00 \\
\hline
\end{tabular}

*Valores de P obtidos de Bertoni e Lombardi Neto (2012) e Roose (1977).

\section{Validation}

The validation of soil loss estimates was done by monitoring the annual sediment transport, according to Beskow et al. (2009). For this purpose, data of total solids in water and respective flow monitored from 1997 to 2010 by two hydrosedimentological stations operated by the Minas Gerais Institute for Water Resources Management (IGAM), located in the municipalities of Cambuquira (MG 473138 W and 7581539 S), and Conceição do Rio Verde (MG, 490706 W and $7572704 \mathrm{~S}$ ). Afterwards, the annual sediment transport was calculated considering the flow of the sub-basins and the daily flow of data obtained from the National Water Agency (ANA). 
The annual sediment transported was compare with the Sediment Delivery Ratio (SDR), which represents the eroded soil fraction that reaches the water bodies. The SDR value is determined according to Equation 5 Vanoni (1975).

\section{$\mathrm{SDR}=0.473 \cdot(0,00386102 * A)^{-0.125}$}

(Equation 5)

Where SDR is Sediment Delivery Ratio (\%); A is basin drainage area (ha).

\section{Soil Loss Tolerance (T)}

The $\mathrm{T}$ was calculated by Equation 6 (Bertol and Almeida, 2000).

$$
\mathrm{T}=\mathrm{h} \times \mathrm{r}_{\mathrm{a}} \times \mathrm{m} \times \mathrm{p} \times \mathrm{Ds} \times 1000^{-1}
$$

(Equation 6)

Where $\mathrm{T}$ is the soil loss tolerance $\left(\mathrm{Mg} \mathrm{ha}^{-1} \mathrm{year}^{-1}\right)$; $\mathrm{h}$ is the effective soil depth $(\mathrm{cm})$, limited to $100 \mathrm{~cm} ; r_{a}$ is the ratio that expresses, mutually, the effect of the textural relationship between the horizons $\mathrm{B}$ and $\mathrm{A}$ and the clay content of the horizon A; m expresses the organic matter content in the $0-20 \mathrm{~cm}$ soil depth; $\mathrm{p}$ is the soil permeability factor; Ds is the soil density $\left(\mathrm{kg} \mathrm{dm}^{-3}\right)$; and 1.000 is the constant that expresses the time period required to wear away a soil layer of 1,000 $\mathrm{mm}$ thickness.

Latosols and Cambisols of the study area present an effective soil depth (h) of $1000 \mathrm{~mm}$ and $800 \mathrm{~mm}$, respectively. The other parameters were determined according to Bertol and Almeida (2000), using the soil analyses results. Both subbasins present a $r_{a}$ of 1 and an $m$ and $p$ of 0.7 , with soil permeability classified as slow. Soil density of Latosols and Cambisols was, respectively, $1.23 \mathrm{~kg} \mathrm{dm}^{-3}$ and $1.21 \mathrm{~kg} \mathrm{dm}^{-3}$ for Ribeirão Jose Lucio and Ribeirão São Bento subbasins.

\section{RESULTS AND DISCUSSION}

The total soil loss of the Ribeirão São Bento subbasin was $1,032 \mathrm{Mg}_{\text {year }}{ }^{-1}$, while the Ribeirão José Lúcio subbasin presents a loss of 5,014 Mg year ${ }^{-1}$. The sediment delivery ratio (SDR) was 0.045 and 0.38 indicating that $45 \%$ and $38 \%$ of eroded sediments in the respective Ribeirão São Bento and Ribeirão José Lúcio subbasins reach the water bodies. Thus, considering the SDR, the average soil loss estimated by RUSLE was 1.41 and $1.22 \mathrm{Mg} \mathrm{year}^{-1} \mathrm{ha}^{-1}$ (Table 6).

We found errors of $0.19 \mathrm{Mg}$ year ${ }^{-1} \mathrm{ha}^{-1}(15.57 \%)$ and $0.25 \mathrm{Mg} \mathrm{year}^{-1} \mathrm{ha}^{-1}$ (19.82\%) comparing RUSLE results with the annual sediment transported calculated using field data (Table 6).

According to Pandey (2007), errors smaller than 20\% allow the validation of the water erosion models. Thus, the results generated by RUSLE illustrate the satisfactory efficiency of the method employed. 
Table 6. Soil loss estimate by RUSLE, annual sediment delivery and estimate errors.

\begin{tabular}{cccc}
\hline Subbasin & $\begin{array}{c}\text { Soil loss rate } \\
\left(\mathrm{Mg} \mathrm{ha}^{-1} \text { year }^{-1}\right)\end{array}$ & $\begin{array}{c}\text { Annual sediment } \\
\text { delivery }\left(\mathrm{Mg} \mathrm{ha}^{-1} \mathrm{year}^{-1}\right)\end{array}$ & $\begin{array}{c}\text { Error } \\
\left(\mathrm{Mg} \mathrm{ha}^{-1} \mathrm{year}^{-1} \mathrm{and}^{\circ}\right)\end{array}$ \\
\hline $\begin{array}{c}\text { José } \\
\text { Lúcio }\end{array}$ & 1.41 & 1.22 & $0.19(15.57)$ \\
São Bento & 1.39 & 1.16 & $0,23(19,82)$
\end{tabular}

$\mathrm{W}_{\mathrm{yr}}=$ Annual erosion; $\mathrm{G}_{\mathrm{yr}}=$ real soil loss;

Areas with exposed soil and steeper slopes have the highest rates of soil loss in both sub-basins (Figure 4).

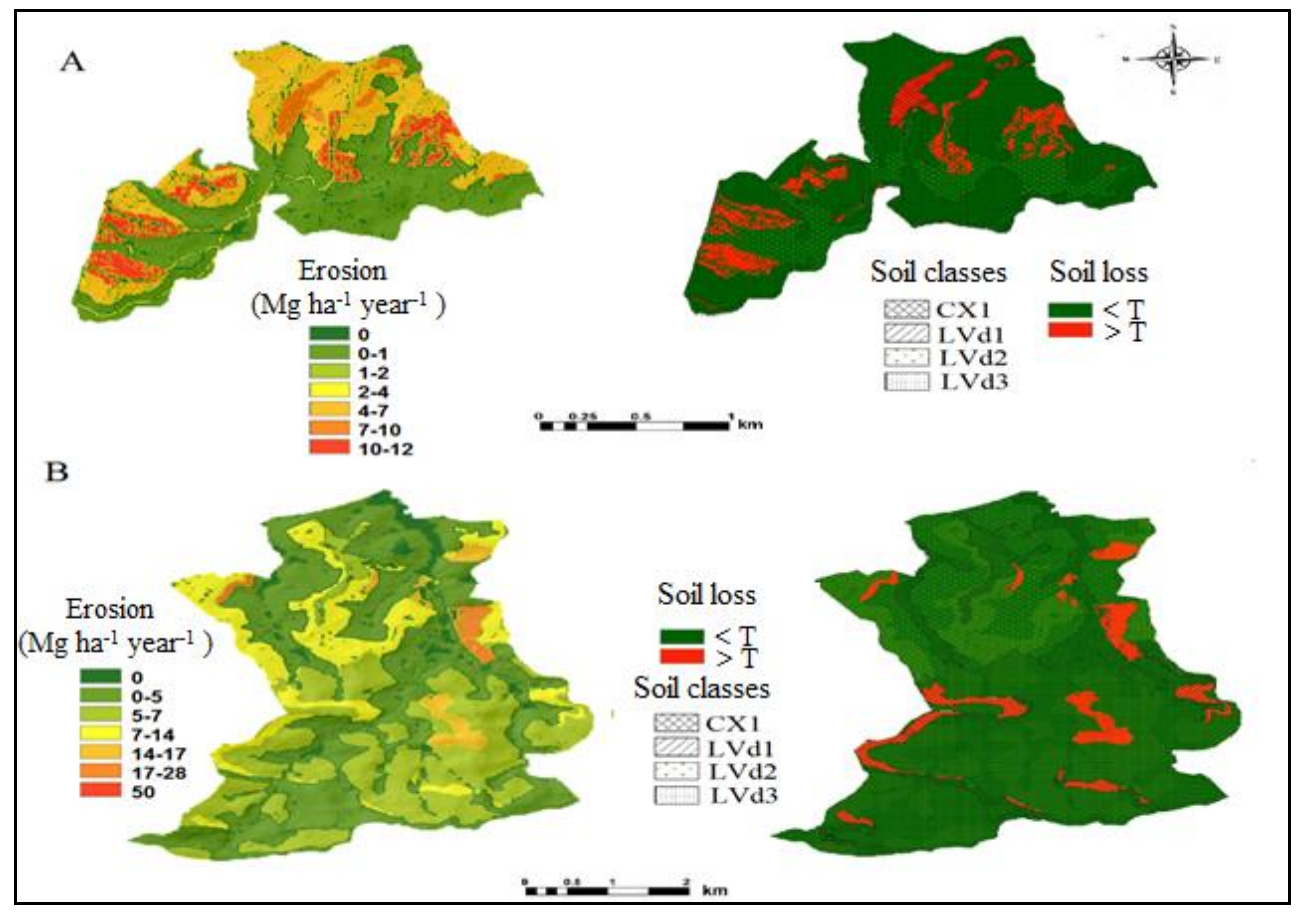

Figure 4: Soil loss rates and Soil Loss Tolerance (T) in the Ribeirão São Bento (A) and Ribeirão José Lucio (B) subbasins in the respective Cambuquira and Conceição do Rio Verde Municipalities, Minas Gerais State, Brazil.

Note: Dystrophic red Latosol in a flat to slightly rolling relief (LVd1), Dystrophic red Latosol in a rolling relief (LVd2), Dystrophic red Latosol in a strongly rolling relief (LVd3).

As expected, due to the greater fragility of Cambisols, the sediment generation rates in each class of land use showed that Cambisols are more susceptible to erosion compared to Latosols (Bertol and Almeida, 2000) (Table 7).

The soil loss rate estimated in the native forest was $0.01 \mathrm{Mg} \mathrm{ha}^{-1}$ year $^{-1}$, similar to Silva et al. (2007) that found soil loss rates range from 0.01 to $0.38 \mathrm{Mg}$ 
$\mathrm{ha}^{-1}$ year $^{-1}$, in a native forest at the Rio Grande do Sul State. The low losses in native forests are due to natural conservation and the protection offered to the soil by the canopy of dense vegetation and litter.

Coffee areas presented average soil loss rates of 4.50 and $5.71 \mathrm{Mg} \mathrm{ha}^{-1}$ year ${ }^{1}$ for the Ribeirão São Bento and Ribeirão José Lucio subbasins, respectively. The highest rates of erosion in coffee were found in young areas, when soil cover by the canopy of coffee trees is still low (Carvalho et al., 2007). The results obtained were lower than the values observed by Silva et al. (1999) (10.98 Mg ha ${ }^{-1}$ year) for Dystrophic Red-Yellow Latosol. These results are due to the conservation practices adopted in the coffee areas, with consequent lower $\mathrm{P}$ factor value $(0.5)$.

Table 7. Soil losses by the land use and occupation classes in the Ribeirão São Bento and the Ribeirão José Lucio subbasins.

\begin{tabular}{|c|c|c|c|c|c|c|}
\hline \multicolumn{4}{|c|}{ Ribeirão São Bento } & \multicolumn{3}{|c|}{ Ribeirão José Lucio } \\
\hline Land use & $\begin{array}{r}\text { Area } \\
\text { (ha) }\end{array}$ & $\begin{array}{c}\text { Area } \\
(\%)\end{array}$ & $\begin{array}{l}\text { Soil loss } \\
\text { Mg ha }^{-1} \\
\text { year }^{-1}\end{array}$ & $\begin{array}{c}\text { Area } \\
\text { (ha) }\end{array}$ & $\begin{array}{c}\text { Area } \\
(\%)\end{array}$ & $\begin{array}{l}\text { Soil loss } \\
\text { Mg ha }^{-1} \\
\text { year }^{-1}\end{array}$ \\
\hline Facilities & 1.17 & 3.35 & 0.00 & 10.01 & 0.73 & 0.24 \\
\hline Coffee & 147.74 & 43.55 & 4.50 & 538.94 & 39.76 & 5.71 \\
\hline $\begin{array}{l}\text { Access } \\
\text { roads }\end{array}$ & 19.88 & 5.86 & 6.27 & 80.20 & 5.91 & 6.33 \\
\hline $\begin{array}{l}\text { Native } \\
\text { forest }\end{array}$ & 94.46 & 27.84 & 0.10 & 669.01 & 49.35 & 0.24 \\
\hline Pasture & 75.95 & 22.31 & 0.21 & 34.04 & 2.51 & 3.01 \\
\hline Eucalyptus & & - & - & 23.18 & 1.71 & 18.24 \\
\hline Total & 332.92 & 100 & - & 1355.39 & 100 & - \\
\hline
\end{tabular}

Eucalyptus showed the highest rate of soil loss among the land use classes (Table 7), due to the young age of the plants, which provides low canopy protection against erosion. The T limits determined for the Ribeirão São Bento and the Ribeirão José Lúcio subbasins were 8.3, 7.5, 7.1 and 6.7 $\mathrm{Mg} \mathrm{ha}^{-1}$ year ${ }^{-1}$, and 6.5, 8.5, 7.5 and $5.5 \mathrm{Mg} \mathrm{ha}^{-1} \mathrm{year}^{-1}$ for the LVd1, LVd2, LVd3, and CX1, respectively. Ribeirão São Bento subbasin has $13.16 \%$ of the area with losses above $\mathrm{T}$, while $7.9 \%$ of the Ribeirão José Lúcio subbasin area exceeded the $\mathrm{T}$ limits.

The $\mathrm{T}$ results obtained are below those found by Bertol and Almeida (2000) for Latosols from Santa Catarina State (10.62 to $12.50 \mathrm{Mg} \mathrm{ha}^{-1} \mathrm{year}^{-1}$ ) and São Paulo State (9.60 to $15.00 \mathrm{Mg} \mathrm{ha}^{-1}$ year $^{-1}$ ) according to Bertoni and Lombardi Neto (2012). This difference may be due to Bertol and Almeida (2000) method considering more attributes related to the soil formation factors in the $\mathrm{T}$ estimation.

Determining the $\mathrm{T}$ is quite difficult due to the difficulties in calculating soil formation rates. For this reason, soil properties, such as organic matter, water permeability in the soil and the textural relationship between horizons B and A, 
which indirectly reflect the rates of soil formation, are used to define $\mathrm{T}$. Conceptually, every soil has a limit $\mathrm{T}$, which is related to your training rate. Thus, $\mathrm{T}$ calculations are complementary to water erosion estimates and allow a more accurate assessment of soil degradation status

Areas with soil losses above $\mathrm{T}$ should be prioritized in the adoption of conservation management practices, seeking to minimize water erosion, and ensuring the long-term sustainability of agricultural production. Better management practices such as terracing, level planting, and cover crops between the coffee lines could mitigate the erosion rates and decrease the runoff, consequently provide the conservation of watercourses, and improve the fertilizer use efficiency, which reduces the production costs (Bertoni and Lombardi Neto, 2012).

Considering the importance of coffee growing in high altitudes and steep areas in the south of Minas Gerais State, the results showed that the adoption of conservationist management practices provide low soil loss rates and contribute to the sustainability of coffee production. The studied subbasins presented distinct values of soil loss susceptibility but similar characteristics in the places most susceptible to erosion. The RUSLE model allowed the identification of areas with soil losses above the limits of $\mathrm{T}$, especially in steep areas with coffee cultivation. Thus, it is an alternative tool for planning land use and management to promote sustainable agricultural systems.

\section{CONCLUSIONS}

Ribeirão São Bento and Ribeirão José Lúcio subbasins soil losses ranged from 0.01 to $28.45 \mathrm{Mg} \mathrm{ha}^{-1}$ year $^{-1}$, with an average of 1.41 and $1.22 \mathrm{Mg}$ year $^{-1}$, respectively. The average soil loss in the coffee cultivation areas was $5.1 \mathrm{Mg} \mathrm{ha}^{-1}$ year ${ }^{-1}$.

Revised Universal Soil Loss Equation modeling of water erosion showed higher losses rates in areas with steeper slopes and without conservation practices. The areas with soil loss above the tolerance limits should be a priority for the adoption of mitigation measures.

The RUSLE model is a fast, simple, and inexpensive tool that contributes to the assessment of soil conservation in hydrographic subbasins.

\section{ACKNOWLEDGEMENTS}

The authors thanks the Ipanema Agricola S.A. for logistical support and financing of the laboratory analyses, the Coordenação de Aperfeiçoamento de Pessoal de Nível Superior - Brazil (CAPES) - Finance Code 001. The authors thanks Fundação de Amparo à Pesquisa do Estado de Minas Gerais (FAPEMIG) for the scholarship and CAPES for the PNPD postdoctoral fellowship. The FAPEMIG contributed under projects CAG-APQ 01053-15 and APQ 00802-18; and CNPQ contributed under projects 306511 / 2017-7 and 202938 / 2018-2. 


\section{REFERENCES}

Alemayehu, G.; Alamirew, T. (2012): Testing and Validation of the Revised Universal Soil Loss Equation (RUSLE-2) at the Twin Catchments of Gununo, Wolaita. PhD diss., Haramaya University.

Amorim, RSS.; Silva, DD.; Pruski, FF.; and Matos, AT. (2010): Avaliação do desempenho dos modelos de predição da erosão hídrica USLE, RUSLE e WEPP para diferentes condições edafoclimáticas do Brasil. Engenharia Agrícola, 30:1046-1059.

Aquino, RF.; Silva, MLN.; Freitas, DAF.; Curi, N.; Mello, CR.; and Avanzi, JC. (2012): Spatial variability of the rainfall erosivity in Southern region of Minas Gerais State, Brazil. Ciência e Agrotecnologia, 36:533-542.

Avanzi, JC.; Silva, MLN.; Curi, N.; Norton, LD.; Beskow, S.; and Martins, SG. (2013): Spatial distribution of water erosion risk in a watershed with eucalyptus and Atlantic Forest. Ciência e Agrotecnologia, 37:427-434.

Ayer, BEJ.; Mincato, LR.; Lammle, L.; Silva, MPFL.; Garofalo, TFD.; Servidoni, EL.; Spalevic, V.; Pereira, YS. (2020): Hydrosedimentological dynamics in the Guarani Aquifer System, Ribeirão Preto, State of São Paulo, Brazil. Agriculture and Forestry, 66 (1): 215-232.

Bertol, I.; and Almeida, JA. (2000): Tolerância de perda de solo por erosão para os principais solos do estado de Santa Catarina. Revista Brasileira de Ciência do Solo. 24:657-668.

Bertol, OJ.; Rizzi, NE.; Bertol, I.; and Roloff, G. (2007): Perdas de solo e água e qualidade do escoamento superficial associadas à erosão entre sulcos em área cultivada sob semeadura direta e submetida às adubações mineral e orgânica. Revista Brasileira de Ciência do Solo, 31:781-792.

Bertoni, J.; and Lombardi-Neto, F. (2012): Conservação do solo. 8th ed. São Paulo: Ícone.

Beskow, S.; Mello, CR.; Norton, LD.; Curi, N.; Viola, MR.; and Avanzi, JC. (2009): Soil erosion prediction in the Grande River Basin, Brazil using distributed modeling. Catena, 79:49-59.

Blake GR and Hartge KH (1986). Methods of Soil Analysis. Part 1. In: Klute A, editor. Physical and Mineralogical Methods. Madison: Soil Science Society of America. p. 363-375.

Bouyoucos, GI. (1962): Hydrometer method improved for making particle size analysis of soil. Agronomic Journal, 472:464-469.

Carvalho, R.; Silva, MLN.; Avanzi, JC.; Curi, N.; and Souza, FS. (2007): Erosão hídrica em Latossolo Vermelho sob diversos sistemas de manejo do Cafeeiro no Sul de Minas Gerais. Ciência e Agrotecnologia, 31:1679-1687.

Chalise, D.; Kumar, L.; Spalevic, V.; Skataric, G. (2019): Estimation of Sediment Yield and Maximum Outflow Using the IntErO Model in the Sarada River Basin of Nepal. Water 2019, 11, 952.

Curovic, Z.; Curovic, M.; Spalevic, V.; Janic, M.; Sestras, P.; Popovic, S.G. (2019): Identification and Evaluation of Landscape as a Precondition for Planning Revitalization and Development of Mediterranean Rural Settlements - Case Study: Mrkovi Village, Bay of Kotor, Montenegro. Sustainability 2019, 11, 2039.

Dimotta, A.; Cozzi, M.; Romano, S.; Lazzari, M. (2016): Soil Loss, Productivity and Cropland Values GIS-Based Analysis and Trends in the Basilicata Region (Southern Italy) from 1980 to 2013; ICCSA 2016, Part IV, Lecture Notes in Computer Science, 9789; Gervasi, O., Ed.; Springer: Cham, Switzerland, 2016; pp. $29-45$. 
Dimotta, A.; Lazzari, M.; Cozzi, M.; Romano, S. (2017): Soil Erosion Modelling on Arable Lands and Soil Types in Basilicata, Southern Italy; ICCSA 2017, Part V, Lecture Notes in Computer Science LNCS, 10408; Gervasi, O., Ed.; Springer: Cham, Switzerland; pp. 57-72.

El Mouatassime, S.; Boukdir, A.; Karaoui, I.; Skataric, G.; Nacka, M.; Khaledi Darvishan, A.; Sestras, P.; Spalevic, V. (2019): Modelling of soil erosion processes and runoff for sustainable watershed management: Case study Oued el Abid Watershed, Morocco. Agriculture and Forestry 65 (4), 241-250.

Empresa Brasileira de Pesquisa Agropecuária - EMBRAPA (2011): Manual de métodos de análises de solos. Rio de Janeiro: Centro Nacional de Pesquisas de Solos EMBRAPA Solos.

Environmental Systems Research Institute - ESRI (2014): ArcGIS Professional GIS for the desktop. Version 10.2.

Galindo, ICL.; and Margolis, E. (1989): Tolerância de perdas por erosão para solos do estado de Pernambuco. Revista Brasileira de Ciência do Solo, 13:95-100.

Girmay, G.; Moges, A. \& Muluneh, A. (2020): Estimation of soil loss rate using the USLE model for Agewmariayam Watershed, northern Ethiopia. Agric \& Food Secur 9, 9. https://doi.org/10.1186/s40066-020-00262-w

Greiner, L.; Kellera, A.; Grêt-Regameyb, A.; and Papritzc, A. (2017): Soil function assessment: review of methods for quantifying the contributions of soils to ecosystem services. Land Use Policy, 69:224-237.

Hazbavi, Z.; Azizi, E.; Sharifi, Z.; Alaei, N.; Mostafazadeh, R.; Behzadfar, M.; Spalevic, V. (2020): Comprehensive estimation of erosion and sediment components using IntErO model in the KoozehTopraghi Watershed, Ardabil Province. Environ. Eros. Res. J. 2020, 10, 92-110.

Hurni, H.; Solomon, A.; Amare, B.; Berhanu, D.; Ludi, E.; Portner, B.; Birru, Y.; Gete, Z. (2010): Land degradation and sustainable land management in the Highlands of Ethiopia In: Hurni H, Wiesmann U, editors. Global change and sustainable development: a synthesis of regional experiences from research partnerships. Perspectives of the Swiss National Centre of Competence in Research (NCCR) North-South, University of Bern, Vol. 5. Bern: Geographica Bernensia; 2010. pp 187-207.

Instituto Brasileiro de Geografia e Estatística - IBGE. 1971. Carta Topográfica do Município de São Lourenço - Folha SF 23-Y-B-III-2 1:50.000. Rio de Janeiro: Ministério do Planejamento e Coordenação Geral.

Instituto Brasileiro de Geografia e Estatística - IBGE. 1979. Carta Topográfica do Município de Varginha - Folha SF 23-V-D 1:250.000. Rio de Janeiro, Secretaria de Planejamento da Presidência da República do IBGE, Diretoria de Geociência e Cartografia, Superintendência de Cartografia.

Instituto Nacional de Pesquisas Espaciais - INPE. 2019. SGI 2.5 Divisão de Geração de Imagens (DIDGI). SGI. Imagem Geosistemas, Instituto Nacional de Pesquisas Espaciais, São José dos Campos.

Khaledi Darvishan, A.; Mohammadi, M.; Skataric, G.; Popovic, S.; Behzadfar, M.; Sakuno, N.; Mincato, R.; Spalevic, V. (2019): Assessment of soil erosion, sediment yield and maximum outflow, using IntErO model (Case study: S8-IntA Shirindarreh Watershed, Iran). Agriculture and Forestry, 65 (4), 203-210.

Lal R. 2014. Desertification and soil erosion. Global Environmental Change, 1:369-378.

Lin, H. (2011): Hydropedology: towards new insights into interactive pedologic and hydrologic processes across scales. Journal of Hydrology, 406:141-145. 
Martins, SG.; Silva, MLN.; Avanzi, SG.; Curi, N.; and Fonseca, S. (2010): Fator cobertura e manejo do solo e perdas de solo e água em cultivo de eucalipto e em Mata Atlântica nos Tabuleiros Costeiros do Estado do Espírito Santo. Scientia Forestalis, 38:517-526.

McBratney, AB.; Santos, MLM and Minasny, B. (2003): On digital soil mapping. Geoderma, 117: 3-52.

Moore ID and Burch GJ. (1986): Physical basis of the length-slope factor in the universal soil loss equation. Soil Science Society American Journal, 50:1294-1298.

Morgan R.P. (2005): Soil erosion and conservation. New York: Wiley.

Munsell Color Company (2012): Munsell soil color charts. Catalog. Baltimore: Macbeth Division of Kollmorgen Corporation.

Nikolic, G.; Spalevic, V.; Curovic, M.; Khaledi Darvishan, A.; Skataric, G.; Pajic, M.; Kavian, A.; Tanaskovik, V. (2018): Variability of Soil Erosion Intensity Due to Vegetation Cover Changes: Case Study of Orahovacka Rijeka, Montenegro. Not. Bot. Horti Agrobot. Cluj-Napoca 2018, 47, 237-248.

Oliveira, AMM.; Pinto, SAF.; and Lombardi-Neto F. (2007): Caracterização de indicadores da erosão do solo em bacias hidrográficas com o suporte de geotecnologias e modelo preditivo. Est. Geogr., 5:63-86.

Olivetti, D.; Mincato, RL.; Ayer, JEB.; Silva, MLN.; and Curi, N. (2015): Spatial and temporal modeling of water erosion in dystrophic red Latosol (oxisol) used for farming and cattle raising activities in a sub-basin in the south of Minas Gerais. Ciência e Agrotecnologia, 39:58-67.

Ouallali, A.; Aassoumi, H.; Moukhchane, M.; Moumou, A.; Houssni, M.; Spalevic, V.; Keesstra, S. (2020): Sediment mobilization study on Cretaceous, Tertiary and Quaternary lithological formations of an external Rif catchment, Morocco. Hydrol. Sci. J. 2020, 65, 1568-1582.

Pandey, A.; Chowdary, VM.; and Mal, BC. (2007): Identification of critical erosion prone areas in the small agricultural watershed using USLE, GIS and remote sensing. Water Resources Management, 21:729-746.

Parsipour, H., Popovic, S., Behzadfar, M., Skataric, G., Spalevic, V. (2019): Cities expansion and land use changes of agricultural and garden lands in peri-urban villages (case study: Bojnurd). Agriculture and Forestry, 65(3): 173-187

Prochnow, D.; Dechen, SCF.; De Maria, IC.; and Castro, M. (2005): Razão de perdas de terra e fator $\mathrm{C}$ da cultura do cafeeiro em cinco espaçamentos, em Pindorama (SP). Revista Brasileira de Ciência do Solo, 29:91-98.

Renard. KG.; Foster, GR.; Weesies, GA.; McCool, DK.; Yoder, DC. (1997): Predicting soil erosion by water: a guide to conservation planning with the Revised Universal Soil Loss Equation (RUSLE). Washington DC, USDA-SCS. 404 p.

Roose E. J. (1997). Application of the Universal Soil Loss Equation of Wischmeier and Smith in West Africa. In: Greenland DJ, Lal R, editors. Soil conservation and management in the humid tropics. (pp. 177-187). Chichester: John Wiley \& Sons.

Santos, HG.; Jacomine, PKT.; Anjos, LHC.; Oliveira, VA.; Oliveira, JB.; Coelho, MR.; Lumbreras, JF.; Cunha, TJF. (2013): Sistema brasileiro de classificação de solos (SiBCS). 3. ed. rev. ampl. Rio de Janeiro: Embrapa Solos; 2013.

Santos, HG.; Jacomine, PKT.; Anjos, LHC.; Oliveira, VA.; Oliveira, JB.; Coelho, MR.; Lumbreras, JF.; Cunha, TJF (2013): Sistema brasileiro de classificação de solos (SiBCS). 3. ed. rev. ampl. Rio de Janeiro: Embrapa Solos; 2013.

Silva AM, Schulz HE and Camargo PB (2007). Erosão e Hidrossedimentalogia em Bacias Hidrográficas. São Carlos: RiMa. 
Silva, BPC.; Silva MLN.; Batista, PVG.; Pontes, LM.; Araujo, EF.; and Curi, N. (2016): Soil and water losses in eucalyptus plantation and natural forest and determination of the USLE factors at a pilot sub-basin in Rio Grande do Sul, Brazil. Ciência e Agrotecnologia, 40:432-442.

Silva, MLN.; Curi, N.; Ferreira, MM.; Lima, JM.; Ferreira, DF. (1999): Proposição de modelos para estimativa da erodibilidade de Latossolos brasileiros. Pesquisa Agropecuária Brasileira, 34:2287-2298.

Spalevic, V. (1999): Application of Computer-Graphic Methods in the Studies of Draining Out and Intensities of Ground Erosion in the Berane Valley. Master's Thesis, Faculty of Agriculture of the University of Belgrade, Belgrade, Serbia, 1999; $135 \mathrm{p}$.

Spalevic, V. (2011): Impact of Land Use on Runof and Soil Erosion in Polimlje. Ph.D. Thesis, Faculty of Agriculture, University of Belgrade, Belgrade, Serbia, 2011; pp. $1-260$.

Spalevic, V., Barovic, G., Fikfak, A., Kosanovic, S., Djurovic, M., and Popovic, S. (2016): Sediment yield and Land use changes in the Northern Montenegrin Watersheds: Case study of Seocki Potok of the Polimlje Region. Journal of Environmental Protection and Ecology. 17 (3): 990-1002

Spalevic, V.; Barovic, G.; Vujacic, D.; Curovic, M.; Behzadfar, M.; Djurovic, N.; Dudic, B.; Billi, P. (2020): The Impact of Land Use Changes on Soil Erosion in the River Basin of Miocki Potok, Montenegro. Water, 12, 2973.

Sparovek, G.; Van-Lier, Q.J.; Dourado-Neto, D. (2007): Computer assisted Köppen climate classification: a case study for Brazil. International Journal of Climatology, 27:257-266.

Tavares, A.S.; Spalevic, V.; Avanzi, J.C.; Nogueira, D.A.; Silva, M.L.N.; Mincato, R.L. (2019): Modeling of water erosion by the erosion potential method in a pilot subbasin in southern Minas Gerais. Semin. Ciências Agrárias 2019, 40, 555-572.

Universidade Federal de Viçosa (UFV), Fundação Centro Tecnológico de Minas Gerais (CETEC-MG), Universidade Federal de Lavras (UFLA), Fundação Estadual do Meio Ambiente (FEAM). 2010. Mapa de Solos do Estado de Minas Gerais: legenda expandida, escala 1:650000. Belo Horizonte: FEAM.

Vanoni V.A. (1975). Sediment deposition engineering. American Society of Civil Engineers: Manuals and Reports on Engineering Practice.

Wischmeier WH and Smith DD (1978). Predicting rainfall erosion losses: a guide to conservation planning. Washington DC: USDA-SCS.

Zhang R. 1997. Determination of soil sorptivity and hydraulic conductivity from the disk infiltrometer. Soil Science Society of America Journal, 61:1024-1030. 